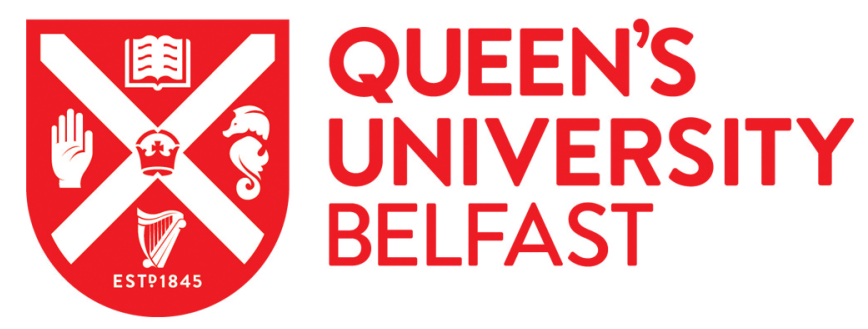

\title{
Neolithic farming in north-western Europe: archaeobotanical evidence from Ireland
}

McClatchie, M., Bogaard, A., Colledge, S., Whitehouse, N. J., Schulting, R. J., Barratt, P., \& McLaughlin, T. R. (2014). Neolithic farming in north-western Europe: archaeobotanical evidence from Ireland. Journal of Archaeological Science, 51, 206-215. https://doi.org/10.1016/j.jas.2012.10.022

Published in:

Journal of Archaeological Science

Document Version:

Peer reviewed version

Queen's University Belfast - Research Portal:

Link to publication record in Queen's University Belfast Research Portal

Publisher rights

Copyright 2012 Elsevier Ltd.

This manuscript version is made available under a Creative Commons Attribution-NonCommercial-NoDerivs License

(https://creativecommons.org/licenses/by-nc-nd/4.0/), which permits distribution and reproduction for non-commercial purposes, provided the author and source are cited.

\section{General rights}

Copyright for the publications made accessible via the Queen's University Belfast Research Portal is retained by the author(s) and / or other copyright owners and it is a condition of accessing these publications that users recognise and abide by the legal requirements associated with these rights.

Take down policy

The Research Portal is Queen's institutional repository that provides access to Queen's research output. Every effort has been made to ensure that content in the Research Portal does not infringe any person's rights, or applicable UK laws. If you discover content in the Research Portal that you believe breaches copyright or violates any law, please contact openaccess@qub.ac.uk. 


\section{Accepted Manuscript}

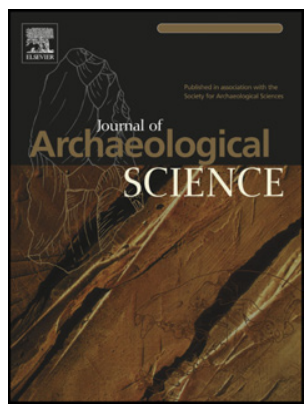

Neolithic farming in north-western Europe: archaeobotanical evidence from Ireland

M. McClatchie, A. Bogaard, S. Colledge, N.J. Whitehouse, R.J. Schulting, P. Barratt, T.R. McLaughlin

PII: S0305-4403(12)00473-6

DOI: 10.1016/j.jas.2012.10.022

Reference: $\quad$ YJASC 3474

To appear in: Journal of Archaeological Science

Received Date: 11 April 2012

Revised Date: 8 October 2012

Accepted Date: 26 October 2012

Please cite this article as: McClatchie, M., Bogaard, A., Colledge, S., Whitehouse, N.J., Schulting, R.J., Barratt, P., McLaughlin, T.R., Neolithic farming in north-western Europe: archaeobotanical evidence from Ireland, Journal of Archaeological Science (2012), doi: 10.1016/j.jas.2012.10.022.

This is a PDF file of an unedited manuscript that has been accepted for publication. As a service to our customers we are providing this early version of the manuscript. The manuscript will undergo copyediting, typesetting, and review of the resulting proof before it is published in its final form. Please note that during the production process errors may be discovered which could affect the content, and all legal disclaimers that apply to the journal pertain. 


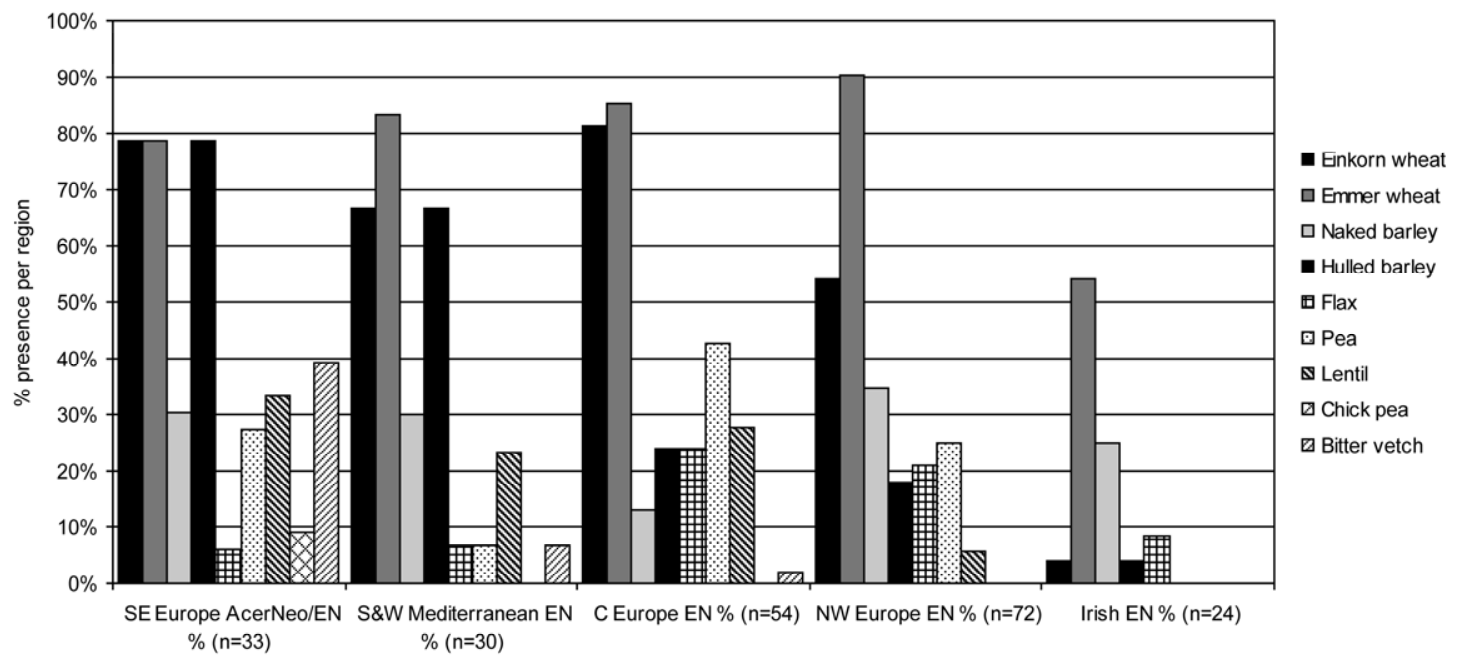




\section{Neolithic farming in north-western Europe: archaeobotanical evidence from Ireland}

McClatchie, M. ${ }^{a}$, Bogaard, A. ${ }^{b}$, Colledge, S. ${ }^{c}$, Whitehouse, N.J. ${ }^{a}$, Schulting, R.J. ${ }^{b}$, Barratt, P. ${ }^{a}$ and McLaughlin, T.R. ${ }^{a}$.

a School of Geography, Archaeology and Palaeoecology, Queen's University Belfast, UK

${ }^{\mathrm{b}}$ School of Archaeology, University of Oxford, UK

${ }^{\mathrm{c}}$ Institute of Archaeology, University College London, UK

\section{Corresponding author}

Meriel McClatchie

Email meriel.mcclatchie@gmail.com

Address: School of Geography, Archaeology and Palaeoecology, Queen's University Belfast, Belfast BT7 1NN, Northern Ireland, UK

Telephone +353 876788044

\section{Introduction}

The introduction of agriculture continues to be an important focus of archaeological and palaeoecological research throughout the world. Ireland lies at the north-western edge of Europe, and farming arrived here around 6000 years ago. International narratives relating to Neolithic agriculture rarely mention the Irish evidence, except as an adjunct to British research. Neolithic farming in Britain is often characterised as transient, with cultivated plant foods being of little economic importance, instead reflecting special or symbolic consumption in 'ritual' contexts (for example, Edmonds, 1999; Thomas, 1999; 2003; 2004; 2008). Others have maintained that crops provided a major component of daily subsistence, as has been proposed for central Europe (Jones, 2000; Monk, 2000; Jones and Rowley-Conwy, 2007; Rowley-Conwy, 2011). Although the British and Irish evidence was considered in tandem for many years, more recent studies have acknowledged differences between the two archaeological records, and it has been suggested that there may 
have been a greater reliance on domesticated resources in Ireland than in Britain (Thomas, 2004, 121), as long argued by some authors (Cooney, 2000; Monk, 2000; see also Bradley, 2007). Current perspectives on arable farming in Neolithic Ireland are based upon a published archaeobotanical dataset of at most 10 sites (for example, Monk, 2000; Colledge et al., 2005; Jones and Rowley-Conwy, 2007). Although cereal remains have been recorded from many more sites, much of the evidence has remained unpublished. This has led to a reliance on a handful of sites as a basis for understanding Neolithic farming throughout Ireland.

New archaeobotanical data from Ireland have recently become available following the many excavations of Neolithic sites over the last two decades, often associated with infrastructural developments (Cooney, 1999; Grogan, 2002; 2004; Smyth, 2006; 2010). A pilot study undertaken in 2007 demonstrated that the available published record did not adequately represent the extent and variety of plant macro-remains from this period (McClatchie, accepted). The pilot study revealed evidence for cereal remains at 24 Neolithic sites, which far exceeded the dataset discussed in previously published studies. Wheat was found to be the dominant crop, being recorded at $79 \%$ of sites (19/24), and it was newly discovered that barley was also significant, being recorded at $67 \%$ of sites (16/24). A review of arable weeds from Irish Neolithic sites has never been undertaken, despite their potential for providing insights into the management of cultivation plots (e.g., Bogaard, 2002; 2004; Bogaard and Jones, 2007). In order to address these issues, a research project, 'Cultivating Societies: assessing the evidence for agriculture in Neolithic Ireland' was undertaken in 2008-2010, funded by the Heritage Council, Republic of Ireland. The project aimed to examine the nature, timing and extent of agricultural activity in Neolithic Ireland through collation and analysis of different strands of published and unpublished archaeological and environmental evidence, with a particular focus on plant macro-remains, pollen, settlement and ${ }^{14} \mathrm{C}$ data (Whitehouse et al., 2010; submitted).

This paper focuses on results from analyses of the plant macro-remains. The main aim of the paper is to review comprehensively the variety and relative occurrence of different plant categories in Neolithic Ireland within its north-west European context, focusing on cultivated plants, but also taking into account other plant groups, such as gathered plants and other wild plants, including arable weeds. The quantities of cereal grains are assessed to explore their frequency of occurrence 
at individual sites, and the ratio of grain/chaff components is established to investigate crop-processing activities. Analyses of arable weed data provide new insights into the management of cultivation plots. Results of further analyses are provided elsewhere (McClatchie et al., in preparation), including more detailed discussion of plant remains and their associated context and site types from different sub-periods of the Neolithic.

\section{Methods of analysis}

Archaeobotanical data were collated from 52 excavated sites (Fig. 1), around two-thirds of which were unpublished at the time of collation. Data were carefully checked for accuracy to ensure a robust dataset, in particular relating to sample location, phasing and dating. A version of the archaeobotanical database created as part of the project is currently available from the project website (www.chrono.qub.ac.uk/instar). In addition to the 52 analysed sites, cereals were recorded at a further 17 Neolithic sites, but the final excavation reports from these sites were incomplete, so they were excluded from analyses (Fig. 1).

Where possible, sites were assigned to the following chronological categories, using new Bayesian site chronologies developed as part of the project (Whitehouse et al., submitted; Schulting et al., in preparation): Early Neolithic (EN I and II), Middle Neolithic (MN I and II) and Late Neolithic (LN) (Table 1). Sites where calibrated date ranges spanned different periods within the Neolithic were assigned to an indeterminate Neolithic category.

The quantity of cereal remains at each site was assessed to investigate their frequency of occurrence, taking into account potential effects of taphonomy and sample size (Jones and Rowley-Conwy, 2007). Where data were available, the number of cereal grains at each site was compared, with three grain fragments counting as one whole grain. This analysis could not be completed for every site, as in a number of cases plant remains were quantified on a ranked scale of abundance (rare, occasional, abundant, etc.) rather than actual counts. At sites where hulled wheat chaff was recorded, a comparison of the quantity of wheat grains and glume bases was undertaken. Each glume base was counted as one chaff component, while spikelet forks (which contain two glume bases) were counted as two components. 
Analysis of potential arable weed remains was restricted to sites where charred weed seeds were found to accompany cereals, as these taxa are likely to represent arable weeds that were growing alongside the cereal crops and inadvertently harvested, and eventually burnt together with the cereals (all cereal remains were preserved by charring). Management of agricultural plots was investigated by analysing the ecological characteristics of potential arable weeds (Wasylikowa, 1981; Engelmark, 1995; Rösch, 2000; Bogaard, 2002; Bogaard and Jones, 2007; Kreuz and Schäfer, 2011). This approach is particularly relevant for exploring Neolithic data, as it can provide insights into whether plots were managed under a shifting cultivation regime, as implied by characterisations of Neolithic farming as transient (for example, Edmonds, 1999; Thomas, 2008), or under a more intensive management system. Ecological characteristics relevant to the permanence of cultivation plots were previously determined during the 'Hambach Forest experiment' in Germany (Bogaard, 2002), where experimental plots on loess soils, cleared of long-lived deciduous woodland, were cultivated over a six-year period and surveyed immediately prior to harvest time in order to document the weed flora. General habitat associations (for example, woodland, disturbed ground) and life cycles of plants (annual versus perennial) were used to determine the types of weeds expected in plots managed under a shifting cultivation regime. In the case of the current study, potential arable weeds encompass those taxa considered to be arable weeds today, as well as a broad range of other herbaceous annuals and perennials that may have grown as weeds in the past (Bogaard, 2002; Bogaard and Jones, 2007). Trees and shrubs were excluded, as they are unlikely to set seed in arable plots. Ecological information for individual taxa was extracted from Ellenberg et al. (1992), and mainly weeds identified to species level were considered (nomenclature follows Stace 1997).

In order to explore the Irish evidence in its wider context, the relative frequency of selected crop types from Neolithic sites across Europe was compared with data from EN II sites in Ireland. The European data derive from a European Neolithic archaeobotany database, which was established as part of an AHRCfunded project 'The origin and spread of Neolithic plant economies in the Near East and Europe' (Shennan and Conolly, 2007).

\section{Overview of database sites and archaeobotanical remains}


Overall, it was found that plant remains were absent from very few Neolithic sites where sampling of deposits for archaeobotanical analysis had been undertaken. In total, plant remains data were examined from $28 \mathrm{EN}$ II sites, $10 \mathrm{MN}$ I sites, $11 \mathrm{MN}$ II-LN sites and three indeterminate Neolithic sites (Table 2). MN II and LN sites were combined due to the small numbers available: five $M N$ II, four $L N$ and two MN II/LN. Plant remains were recorded in a total of 437 samples from 390 contexts - the vast majority of plant remains were preserved through charring, with waterlogged remains occurring at only three sites. Hazelnut shell remains (Corylus avellana L.) were most commonly found, being recorded at $87 \%$ of sites, and were closely followed by cereal remains, which were present at $77 \%$ of sites (Fig. 2). The remains of wild plants other than trees, nuts, fruits and legumes - including potential arable weeds - were found at $46 \%$ of sites, and fruit remains were present at $19 \%$ of sites, consisting mainly of crab-apple (Malus sylvestris L.) seeds and endocarp (core) fragments, as well as seeds from species of the bramble genus (Rubus spp.).

Flax (Linum usitatissimum L.) and legume remains (indeterminate to genus/species) were relatively rare. Direct AMS ${ }^{14} \mathrm{C}$ dating of flax seeds from the EN II site at Clowanstown 1, Co. Meath (UBA-14733, $5003 \pm 32$ BP, 3942-3701 cal BC) established that flax was amongst the earliest crops to be cultivated in Ireland. No definite evidence for cultivated legumes was found - the legumes referred to in Fig. 2 represent finds of the Fabaceae family, which includes both cultivated and wild legumes. Although pea (Pisum sativum L.) remains were recorded in a Neolithic deposit at Castletown Tara 1, Co. Meath (Archaeology Services Durham University, 2009a), they were excluded from analysis when direct $A M S{ }^{14} \mathrm{C}$ dating placed them in the medieval period (UBA-14682, $374 \pm 28 \mathrm{BP}$, cal AD 1447-1631).

No plant macro-remains were identified from any site dating to $4000-3750 \mathrm{cal}$ $B C(E N I)$, traditionally thought to represent the appearance of the Neolithic in Ireland. The scarcity of any type of archaeological evidence that can be securely dated to this period is further discussed by Whitehouse et al. (submitted). Perhaps surprisingly, cereals were present at $86 \%$ and $90 \%$ of EN II and $\mathrm{MN}$ I sites respectively, but at only $36 \%$ of MN II-LN sites. It is unclear if this reflects an actual reduction in cereal usage during this later period, or perhaps changes in how cereal remains entered the archaeological record, such as changes in food preparation and disposal patterns, and changes in settlement types (e.g. the scarcity of 'houses'). 


\section{Cereal remains}

Wheat (Triticum) remains were recorded at $73 \%$ of sites where cereals were present, while barley (Hordeum) was found at $50 \%$. A range of wheat and barley types was recorded (Fig. 3), including emmer wheat (Triticum dicoccum Schübl.), possible einkorn wheat (Triticum monococcum L.), naked wheat (Triticum aestivum/durum/turgidum L.), naked barley (Hordeum vulgare L. var. nudum) and hulled barley (Hordeum vulgare L.). Emmer wheat was the dominant cereal type, in terms of both ubiquity and abundance, most notably during the EN II and MN I periods. Naked wheat remains were found at more than $15 \%$ of sites, although it should be noted that these remains consisted of grains rather than chaff (the latter being a more reliable indicator of cereal species). Possible einkorn wheat remains were found at one site. Naked barley was more often recorded than hulled barley, particularly during the EN II period. Cereal remains were present at a small number of MN II-LN sites (4/11), including emmer wheat, naked wheat and indeterminate barley. A lack of data precludes determination of the relative importance of cereal types during this later period.

\subsection{Quantities of cereal remains}

At the 30 sites where this analysis could be undertaken, the vast majority were found to contain small quantities of cereal grains, usually between one and 25 grains (Fig. 4). In some cases, this may reflect sampling strategies - larger quantities of cereal grains were more often present at sites where more samples were taken. The number of samples taken (and the proportion of these that contained plant remains) could not, however, be established for all sites. Large cereal assemblages (i.e. more than 100 grains) were recorded at five sites, four of which date to the EN II period: EN II rectangular structures at Tankardstown South, Co. Limerick (Monk, 1988; in preparation) and Caw, Co. Derry (Vaughan-Williams, 2007); EN II possible structure at Caherabbey Upper, Co. Tipperary (Halwas, 2007); EN II burnt mounds at Clowanstown 1, Co. Meath (Archaeology Services Durham University, 2009b); and indeterminate Neolithic activity at Castletown Tara 1, Co. Meath (Archaeology Services Durham University, 2009a). 


\subsection{Comparison of cereal grain and chaff quantities}

Hulled wheat spikelet forks and glume bases constitute the predominant form of chaff on Neolithic sites throughout Ireland, Britain and central Europe, probably because this type of chaff is removed from the grain at quite a late stage in crop processing (Bogaard and Jones, 2007, 363). Comparison of the numbers of cereal grains and chaff was possible for four sites (Table 3): rectangular structures at Ballinglanna North, Co. Cork (Johnston, 2010) and Tankardstown South, Co. Limerick (Monk, 1988; in preparation); burnt mounds at Clowanstown 1, Co. Meath (Archaeology Services Durham University, 2009b) and pit complex at Kerloge, Co. Wexford (McClatchie, 2003; 2007). It was found that cereal grains were dominant at each site - the ratio of cereal grains to chaff was at least 2:1. It should, however, be noted that chaff remains are less robust than cereal grains, and chaff can therefore be under-represented (Boardman and Jones, 1990).

\section{Analysis of potential arable weeds}

Charred weed seeds accompanied by cereals were found at a total of 18 sites (35\% of all sites). Assessment of the variety of weed taxa at each site indicated that only one weed species/genus was recorded at the majority of sites (Table 4). The most commonly recorded taxa (found at the highest number of sites) included Avena spp. (oat, which is thought to represent a weed rather than a cultivated crop during this period), Galium aparine L. (cleavers) and Plantago lanceolata L. (ribwort plantain). Between one and five charred weed seeds were recorded at $69 \%$ of 16 sites where charred weed seeds had been quantified. In many cases, therefore, a small quantity and variety of charred weed seeds were present at each site.

\subsection{Ecological profile of potential arable weeds}

Previous studies have established that arable weed flora associated with shifting cultivation are likely to have been dominated by perennial taxa, particularly woodland perennials, while dominance by annual taxa is likely to be indicative of more long-lived cultivation plots (Bogaard, 2002; Bogaard and Jones, 2007). 
Analysis of data from Neolithic sites in the central European loess belt, Britain and Ireland show that potential arable weed taxa are dominated by plants of disturbed places (Fig. 5; Table 5). More than $60 \%$ of examined taxa from central Europe and Britain consisted of plants associated with disturbed habitats, while less than 5\% represented woodland taxa (data from Bogaard and Jones, 2007; accepted). Although the Irish Neolithic dataset is smaller than that from Britain or central Europe, it appears to follow a similar trend, in that taxa associated with disturbed places are dominant and woodland taxa are rare. Freshwater/moorland taxa occurred more often in the Irish dataset, but these reflect local conditions at one site (Clowanstown 1).

Analysis of the life-cycle of potential arable weeds from Neolithic sites in Britain and central Europe shows that the proportions of annual and perennial taxa are roughly evenly split (Fig. 6; data from Bogaard and Jones, 2007; accepted). In the case of Ireland, it is noticeable that more annual than perennial taxa are recorded, although the dataset is smaller. In common with Neolithic Britain and central Europe, the evidence from Ireland clearly does not resemble the picture expected for newly cleared plots managed under a shifting cultivation regime.

\section{The Irish evidence within its wider context}

Comparison of the Irish Early Neolithic evidence with a European archaeobotany database (Shennan and Conolly, 2007) revealed a number of new, insights. The relative frequency of selected crop types from Early Neolithic sites across different regions has been established, focusing on einkorn wheat, emmer wheat, naked barley, hulled barley, flax, pea, lentil, chick pea and bitter vetch. These crops began to emerge in south-west Asia during the ninth millennium cal BC. From south-west Asia, via the eastern Mediterranean, farming spread into south-east Europe, arriving in southern Greece by c. 7000 cal BC, and reaching Ireland, Britain and Scandinavia around 3000 years later (Colledge et al., 2005, 137).

It was found that a wide range of crops was cultivated by the first farmers in south-eastern Europe (Fig. 7). This suite of crops became gradually more restricted as agriculture spread through Neolithic Europe towards Ireland, as noted in previous studies (for example, Colledge et al., 2005; Kreuz et al., 2005; Conolly et al., 2008). Since completion of the European database, more recent studies further indicate that 
a restricted variety of crops are found in Early Neolithic deposits across northern and central Europe when compared with southern regions (for example, Out, 2010; Salavert, 2011), although regional variations within the northern/north-western European record have been highlighted in a recent review (Kirleis et al., 2012).

Drawing upon data from the European database, the overall picture from north-west Europe (Britain, Denmark and Sweden) indicates that naked barley was recorded at a larger number of sites than hulled barley; this trend can also be seen in the new Irish dataset. While einkorn wheat was found at $54 \%$ of sites in north-west Europe, emmer wheat was more often present, being recorded at $90 \%$ of sites. In the case of Ireland, the new dataset revealed that emmer was also the dominant cereal type, but there was remarkably little evidence for einkorn. Pea, lentil (Lens culinaris Medik.), chick pea (Cicer arietinum L.) and bitter vetch (Vicia ervilia L.) Willd.) have not been recorded from Neolithic Ireland, although there is some evidence for flax.

Einkorn was very rare at Irish sites - possible einkorn grains were recorded at just one site (Tankardstown South). Einkorn grains and chaff have been tentatively identified at another site (Ballygalley, Co. Antrim), although analysis is incomplete (Simpson, 1995). Clearer evidence comes from an impression of an einkorn spikelet fork on the surface of an Early Neolithic ceramic vessel at Dooey's Cairn court tomb, Ballymacaldrack, Co. Antrim (Jessen and Helbaek, 1944, 18; Fig. 8). Thus, while both emmer and einkorn were introduced into Ireland during the Early Neolithic period, it appears that there was a low uptake of einkorn cultivation, and it did not spread to any great extent. Ireland is not the only region where einkorn was very rare. The ubiquity of einkorn in selected regions of northern and western Europe was established via the European database (Fig. 9). While it is acknowledged that the European database contains relatively few sites from some regions (e.g. northern France), it does appear that Early Neolithic Britain and northern France similarly have relatively little evidence for einkorn cultivation, perhaps suggesting a regional preference.

\section{Discussion}

This study represents the most comprehensive analysis to date of plant macro-remains from Neolithic Ireland. Published and unpublished sources revealed evidence for a much larger quantity of Irish data than previously acknowledged. 
Every effort was made to ensure that the dataset was reliable and supported by highprecision radiocarbon dating (Whitehouse et al., submitted). Data from a total of 52 sites were analysed, representing one of the largest Neolithic datasets from any individual European country that has been subjected to such detailed investigation.

Cereals were found at a large number of sites dating to the earlier Neolithic, with a notable decrease in their recovery from later sites. Emmer wheat was the dominant crop, at least during the earlier period. Crops other than cereals, such as flax, were present, but comparatively rare. Although the Neolithic period in Ireland is thought to have started at around $4000 \mathrm{cal} \mathrm{BC}$, there is no clear evidence for the presence of cereals until c. 3750 cal BC. This fits well with Cooney et al.'s (2011, 663) recent evaluation for the appearance of the Neolithic in Ireland, in particular their Bayesian Model 2 (3750-3680 cal BC), which agrees with our chronological analyses (cf. Whitehouse et al., submitted). In common with Britain, it appears that a rather narrow range of crops was produced in Ireland when compared to other areas of Europe.

\subsection{The significance of cultivated and wild plant remains}

This study has established that soon after their arrival into Ireland, cereals were being utilised in most areas of the island within a remarkably short space of time (during the EN II period: $3750-3600 \mathrm{cal} \mathrm{BC).} \mathrm{Neolithic} \mathrm{food} \mathrm{procurement} \mathrm{in}$ north-western Europe has sometimes been interpreted as focused on either gathering or cultivation, without recognising that the two are not incompatible. While many different communities around Ireland were incorporating cereals into their activities in different locations and circumstances, they were also making use of locally available wild resources, such as nuts, fruits, tubers and leafy greens, which would have thrived along the edges of cleared ground (Groenman van Waateringe, 1983). The use of wild resources has similarly been recognised by researchers studying northern and central European Neolithic sites (Marinova and Thiebault, 2008; Jacomet, 2007; Kirleis et al., 2012).

Many of the Irish sites produced small quantities of cereal grains, although $10 \%$ of sites did contain larger assemblages (over 100 grains), for example, more than 1000 cereal grains were recovered from EN II houses at Tankardstown South (Monk, 1988; in preparation). The potential effect of sampling strategies on the 
record, as noted above, highlights the need for extensive sampling of deposits when excavating Neolithic sites. Grain density per litre could not be ascertained for the vast majority of sites due to a lack of relevant data (e.g. volume of soil sample processed), although it appears to have been low in many cases. Grain densities per litre of sediment in Britain were similarly calculated to be low (usually less than one grain per litre of sediment), as was also the case at some sites in central Europe (Bogaard and Jones, 2007, 363; accepted).

The small number of cereal grains recorded at most Irish sites need not imply that cereals were of minor importance to Neolithic communities, as suggested by some commentators (for example, Thomas, 2004). As argued elsewhere, recovery of low numbers of cereals may be related to taphonomic issues affecting how charred plant macro-remains enter the archaeological record (Jones, 2000; Jones and Rowley-Conwy, 2007). Cereals persistently occur at different types of sites, particularly during the earlier Neolithic, reflecting their use in different circumstances and by various communities. The widespread occurrence of cereal grains at low levels is consistent with generally small-scale production and occasional, but recurrent, accidental charring (sensu van der Veen and Jones, 2006; Fuller et al., accepted). This situation can be contrasted with evidence from 'house' sites in Bronze Age Ireland (2500-700 cal BC), where substantial grain-rich cereal assemblages are more often found, perhaps reflecting larger-scale production, as well as other social and economic changes, for example in relation to storage facilities and redistributive networks (McClatchie, 2009).

\subsection{Comparison of cereal grains and chaff}

Hulled wheat chaff remains that could be securely dated to the Neolithic period were recorded at only four of the examined sites. In all four cases, cereal grains, rather than chaff, were predominant. Even though hulled wheat - specifically emmer wheat - was the predominant cereal type of Neolithic Ireland, relatively little wheat chaff entered the archaeobotanical record. A study of plant remains from Neolithic sites in Britain found that those contexts yielding hulled wheat chaff similarly contained a low density of material; less than 10 glume bases per litre of sediment (Bogaard and Jones, 2007, 364). At the vast majority of Irish sites, the number of litres of sediment processed was not recorded, thereby preventing analysis on this 
basis, but it is notable that chaff was absent from many sites, and where present, it was recorded in relatively small quantities. A sharp contrast to the Irish and British evidence can be found at some LBK sites in central Europe, where samples containing higher abundances and densities of glume bases per litre of sediment are common (Kreuz et al., 2005; Bogaard and Jones, 2007, 364; Kirleis and Willerding, 2008).

Potential reasons for differences between these regions have previously been suggested (Bogaard and Jones, 2007, 365-6). In central Europe, hulled wheats may have been stored in spikelet form, leading to frequent dehusking on site, as opposed to the storage of clean grain in Ireland and Britain. It is also possible that chaff was used as fodder in Ireland and Britain, and did not enter the archaeobotanical record in any great quantities. It has also been suggested that if chaff was used as fuel in central Europe, it would have been more likely to become charred and enter the archaeobotanical record (Bogaard and Jones, 2007, 365-6). It is likely, therefore, that the differing records reflect distinct patterns of crop processing and subsequent disposal of this material.

\subsection{Investigating the management of crops: the contribution of weed seeds}

In many parts of Europe, it was previously assumed that shifting cultivation was the earliest method by which farming was practised, eventually giving way, perhaps during the Bronze Age, to more intensive practices (for example, Barrett 1994, 144-9). Analyses of potential arable weeds from Neolithic sites in central Europe and Britain (Bogaard and Jones, 2007, 367; accepted) and now Ireland do not support this model. A shifting cultivation regime should be represented by a dominance of perennial taxa, particularly woodland perennials. The evidence from central Europe, Britain and Ireland indicates that shifting cultivation was not taking place, as plants associated with disturbed ground dominate the weed assemblages, and annuals are common. This evidence suggests that the earliest farmers in these regions were instead intensively managing relatively long-lived plots (at least 10 years; Bogaard and Jones, 2007). Communities were therefore creating a sense of place not only in the construction and renovation of houses (Smyth, 2006; 2010) and mortuary monuments (Schulting et al., 2012), but also in their engagement with the 
wider landscape and repeated investment in particular patches of land (Bogaard and Jones, 2007, 367).

\subsection{Comparison of Irish record with evidence from elsewhere in Europe}

A decrease in the diversity of crops can clearly be seen as the earliest agriculture spread north-westwards from south-east Europe. Many Neolithic sites in south-west Asia, south-east Europe, and the central and south-west Mediterranean area have provided evidence for a wider range of cereals and pulses, whereas in central Europe, a narrower range of cereal crops is recorded, and pulses are usually restricted to pea and lentil (Bogaard, 2004; Colledge et al., 2005, 144; Kreuz et al., 2005; Out 2010). By the time farming reached Ireland and Britain, the range of cereal crops is further restricted, and evidence for any pulses is very poor. This has been interpreted as evidence for agriculture becoming more narrowly focused as it entered central Europe, reflecting both environmental and cultural factors (Colledge et al., $2005,144)$. There appears to have been less widespread use of pulses, for example, beyond the areas in which wild progenitors can be found, which may reflect environmental constraints (Zohary and Hopf, 2000, 94-124; Colledge et al., 2005, 145, 149-150).

Examining the evidence from England in more detail (data from Jones and Rowley-Conwy, 2007), cereals were present at $82 \%$ of sites dating to the earlier Neolithic period (total sites $n=33$ ) and $78 \%$ of sites from the later Neolithic period (total sites $n=27$ ). A decrease in the recovery of cereals from later Neolithic sites in England is not as apparent as can be seen in Ireland. Wheat (usually the hulled variety) was recorded at almost $80 \%$ of earlier Neolithic English sites, and at just over $60 \%$ of sites from the later Neolithic period. Barley was present at around half of the sites dating to the earlier Neolithic period and at just over $60 \%$ of sites from the later Neolithic period. It could be suggested that barley became increasingly important during the later Neolithic period in England, but the picture from later Neolithic Ireland is less clear due to a lack of data. It is worth noting, however, that wheat continued to be an important crop in Early-Middle Bronze Age Ireland (2500-1200 cal BC), and a clear shift towards barley production at the expense of wheat did not occur until the Late Bronze Age, beginning at 1200 cal BC (McClatchie, 2009). 
In a recent review of Neolithic plant remains from Scotland (Bishop et al., 2009), evidence from a total of 75 sites provides a sharp contrast to the Irish evidence. In most cases, barley appears to have been the main cereal crop in Neolithic Scotland, with naked barley more commonly found than hulled. This preference for barley was particularly striking at sites near the Atlantic coast in Scotland, perhaps reflecting environmental restraints in terms of the types of crops that could be successfully grown (Bishop et al., 2009). Interestingly, emmer wheat was dominant at a number of Early Neolithic rectangular house structures in Scotland. Emmer wheat was also the dominant crop at rectangular houses (albeit smaller in scale) from EN II Ireland - a period to which these structures are very much restricted (Cooney et al., 2011; McSparron, 2008; Whitehouse et al., 2010; submitted). Naked wheat was recorded on just a few sites in Scotland, but sometimes in large quantities; where naked wheat was recorded at Irish sites, it occurred in small quantities.

While einkorn appears to have been a minor crop in many areas of northern/north-western Europe (Kirleis et al., 2012), the very low occurrence of einkorn at Neolithic Irish and British sites is striking. Although based on a small dataset, it appears that there is also relatively little evidence for einkorn in northern France, perhaps hinting at a source for the spread of agriculture from continental Europe to Ireland and Britain, if crop packages can act as an indicator of origin. Collation of further records from northern France is required to test this hypothesis. The potential link with northern France is interesting and worthy of further exploration, given that similarities in other aspects of the archaeological record between Ireland and northern France have previously been identified, such as pottery styles and tomb design (Sheridan, 2003; 2010).

\section{Conclusions}

This study represents the first comprehensive analysis and synthesis of cereal crops and arable weeds from Neolithic archaeological deposits in Ireland, and a wider comparison with other areas of Europe. The presence of cereals at many sites in Ireland suggests that a range of communities engaged in cereal use and perhaps cultivation in a variety of locations and circumstances. The earliest evidence for cereals dates to a period following $3750 \mathrm{cal} \mathrm{BC}$, which coincides with recent research 
that has re-evaluated the start of the Irish Neolithic (Cooney et al., 2011; Whitehouse et al., submitted). Whether earlier remains of cereal crops will be found remains an open question, but, if so, they are likely to be rare, ephemeral occurrences.

A variety of crops was cultivated - emmer wheat was predominant, but there is also regular evidence for barley (naked and hulled), as well as occasional evidence for einkorn wheat, naked wheat and flax. Although cereals were usually recorded in rather small quantities, their persistent occurrence in the earlier Neolithic archaeological record is striking. It is notable that there is significantly less evidence for cereal remains in later Neolithic Ireland. As well as cultivated crops, many sites also yielded evidence for potentially gathered foods, including hazelnuts and fruits.

The record from Neolithic Ireland compares well with Britain in terms of the types of crops and cultivation practices, as revealed by analysis of potential arable weeds. As in other parts of northern Europe, it appears that the earliest farmers in Ireland were not engaged in shifting cultivation, but rather created a sense of place and 'ownership' by investing in longer-term fixed-plot agriculture. The overall results from this study enable Ireland to be considered in more detail when exploring the spread and development of agriculture across Neolithic Europe - previously unachievable due to the unpublished nature of much of the Irish data - and emphasise the international significance of this new dataset.

\section{Acknowledgements}

The work reported here was funded by the Heritage Council, Republic of Ireland under the INSTAR programme 2008-10 for the project Cultivating Societies: Assessing the Evidence for Agriculture in Neolithic Ireland (Ref: 16682 to Whitehouse, Schulting, Bogaard \& McClatchie). We would like to express our thanks to all our project partners, who provided invaluable advice and assistance: Jane Bunting (University of Hull); Finbar McCormick (QUB); Finola O'Carroll (CRDS Ltd, Republic of Ireland); Alison Sheridan (National Museums Scotland); Jessica Smyth (University of Bristol); Rónán Swan (National Roads Authority, Republic of Ireland); Graeme Warren (University College Dublin). We would also like to thank the reviewers of this paper for their helpful comments.

The following organisations and individuals are thanked for providing access to data and discussing analyses: ACS Ltd; ADS Ltd; Aegis Archaeology Ltd; AML 
Archaeology Ltd; Arthur ApSimon; CAF, Queen's University Belfast; Dr James Conolly; CRDS Ltd; Dept of Archaeology, University College Cork; Catherine Dunne; Eachtra Archaeological Projects Ltd; Dr Allan Hall; Headland Archaeology Ltd; IAC Ltd; Institute of Archaeology, University College London; Judith Carroll Network Archaeology Ltd; Kilkenny Archaeology; Susan Lyons; Margaret Gowen and Co. Ltd; NAC Ltd; National Monuments, Department of Arts, Heritage and the Gaeltacht; National Museum of Ireland; National Roads Authority; School of Archaeology, University College Dublin; Prof. Stephen Shennan; Stafford McLoughlin Archaeology Ltd; TVAS Ireland Ltd; Ulster Museum; Valerie J. Keeley Ltd.

\section{References}

Archaeological Services, University of Durham, 2009a. Appendix 7: environmental report, in: Elder, S.D., M3 Clonee-North of Kells Motorway. Report on the archaeological excavation of Castletown Tara 1, Co. Meath. Ministerial Directions No. A008/025. E3078. ACS Ltd. Available at http://www.m3motorway.ie/Archaeology/Section2/CastletownTara1/; Last accessed $23^{\text {rd }}$ January 2012.

Archaeology Services Durham University, 2009b. Appendix 17: Environmental report. Clowanstown 1, M3 Motorway Project, Co. Meath, Ireland. Plant macrofossil, charcoal, cremated bone and mollusc analysis, in: M. Mossop, E. Mossop, M3 Clonee-North of Kells. Contract 2 Dunshaughlin-Navan. Report on the Archaeological Excavation of Clowanstown 1, Co. Meath. Ministerial Directions No. A008/011. E3064. ACS Ltd. Available at http://www.m3motorway.ie/Archaeology/Section2/Clowanstown1/; Last accessed 23 ${ }^{\text {rd }}$ January 2012.

Barrett, J.C., 1994. Fragments from antiquity: an archaeology of social life in Britain, 2900-1200 BC. Blackwell, Oxford.

Bishop, R.R., Church, M.J., Rowley-Conwy, P.A., 2009. Cereals, fruits and nuts in the Scottish Neolithic. Proc. Soc. Antiquaries Scotland 135, 47-103. 
Boardman, S., Jones, G., 1990. Experiments on the effects of charring on cereal plant components. J.Arch. Sci. 17, 1-11.

Bogaard, A., 2002. Questioning the relevance of shifting cultivation to Neolithic farming in the loess belt of Europe: evidence from the Hambach Forest experiment. Vegetation History and Archaeobotany 11(1-2), 155-168.

Bogaard, A., 2004. Neolithic farming in central Europe. Routledge, London.

Bogaard, A., Jones, G., 2007. Neolithic farming in Britain and central Europe: contrast or continuity? Proc. Br. Acad. 144, 357-375.

Bogaard, A., Jones, G., (accepted). Assessing the nature and role of Neolithic cultivation: recent work and future prospects in central Europe and Britain, in: Whitehouse, N., Schulting, R., McClatchie, M. (Eds.), Living landscapes: exploring Neolithic Ireland and its wider context.

Bradley, R., 2007. The prehistory of Britain and Ireland. Cambridge University Press, Cambridge.

Colledge, S., Conolly, J., Shennan, S., 2005. The evolution of Neolithic farming from SW Asian origins to NW European limits. Eur. J. Archaeol. 8, 137-156.

Conolly, J., Colledge, S., Shennan, S., 2008. Founder effect, drift, and adaptive change in domestic crop use in early Neolithic Europe. J. Archaeol. Sci. 35, 27972804.

Cooney, G., 1999. A boom in Neolithic houses. Archaeol. Irel. 13(1), 13-16.

Cooney, G., 2000. Landscapes of Neolithic Ireland. Routledge, London.

Cooney, G., Bayliss, A., Healy, F., Whittle, A., Danaher, E., Cagney, L., Mallory, J., Smyth, J., Kador, T., O'Sullivan, M., 2011. Ireland, in: Whittle, A., Healy, F., Bayliss, 
A. (Eds.), Gathering time: dating the Early Neolithic enclosures of southern Britain and Ireland. Volume 1. Oxbow Books, Oxford, pp. 562-681.

Edmonds, M., 1999. Ancestral geographies of the Neolithic: landscape, monuments and memory. Routledge, London.

Ellenberg, H., Weber, H.E., Düll, R., Wirth, V., Werner, W., Paulissen, D., 1992. Zeigerwerte von Pflanzen in Mitteleuropa. Scripta Geobotanica 18.

Engelmark, R., 1995. Experiments concerning prehistoric slash-and-burn agriculture (in Swedish with English summary), in: Larsson, B. (Ed.), Svedjebruk och röjningsbränning I Norden - terminology, datering, metoder. Nordiska museet, Stockholm, pp. 28-36.

Fuller, D., Stevens, C., McClatchie, M., (accepted). Routine activities, tertiary refuse and labor organization: social inferences from everyday archaeobotany, in Madella, M., Savard, M. (Eds.), Ancient plants and people - contemporary trends in archaeobotany. University of Arizona Press, Tucson.

Groenman van Waateringe, W., 1983. The early agricultural utilization of the Irish landscape: The last word on the elm decline?, in: Reeves-Smith, T., Hamond, F. (Eds.), Landscape archaeology in Ireland. British Archaeological Reports International Series 116. B.A.R., Oxford, pp. 217-232.

Grogan, E., 2002. Neolithic houses in Ireland: a broader perspective. Antiquity 76, 517-525.

Grogan, E., 2004. The implications of Irish Neolithic houses, in: Shepherd, I.A.G., Barclay, G.J. (Eds.), Scotland in ancient Europe: The Neolithic and Early Bronze Age of Scotland in their European context. Society of Antiquaries of Scotland, Edinburgh, pp. 103-114.

Halwas, S., 2007. Appendix 5: Analysis of carbonized plant remains, in: Molloy, B., Final Report: Caherabbey Upper, Co. Tipperary. N8 Cashel to Mitchelstown Road 
Improvement Scheme, 35-40. Margaret Gowen and Co. Ltd, Unpublished excavation report.

Jacomet, S., 2007. Neolithic plant economies in the northern Alpine Foreland from 5500-3500 cal BC, in: Colledge, S., Conolly, J. (Eds.), The origins and spread of domestic plants in southwest Asia and Europe. Left Coast Press, California, pp. 221258.

Jessen, K., Helbaek, H., 1944. Cereals in Great Britain and Ireland in prehistoric and early historic times. Det Kongelige Danske Videnskabernes Selskab Biol. Skrifter $3(2), 1-68$.

Johnston, P., 2010. Appendix 5: plant remains, in: Johnston, P., Tierney, J. (Eds.), Archaeological excavation report: two Neolithic structures and two fulachta fiadh. Ballinglanna North 3, Co. Cork, 194-203. Eachtra Journal 10. Available at http://eachtra.ie/index.php/journal/issues/10/; Last accessed on 23 ${ }^{\text {rd }}$ January 2012.

Jones, G., 2000. Evaluating the importance of cultivation and collecting in Neolithic Britain, in: Fairbairn, A.S. (Ed.), Plants in Neolithic Britain and beyond. Oxbow, Oxford, pp. 79-84.

Jones, G., Rowley-Conwy, P., 2007. On the importance of cereal cultivation in the British Neolithic, in: Colledge, S., Conolly, J. (Eds.), The origins and spread of domestic plants in southwest Asia and Europe. Left Coast Press, California, pp. 391419.

Kirleis, W., Klooß, S., Kroll, H., Müller, J., 2012. Crop growing and gathering in the northern German Neolithic: a review supplemented by new results. Vegetation History and Archaeobotany 21(3), 221-242.

Kirleis, W., Willerding, U., 2008. Die Pflanzenreste der linienbandkeramischen Siedlung von Rosdorf-Mühlengrund, Ldkr. Göttingen, im südöstlichen Niedersachsen. Prähistorische Zeitschrift 83(2), 133-178. 
Kreuz, A., Marinova, E., Schäfer, E., Wiethold, J., 2005. A comparison of Early Neolithic crop and weed assemblages from the Linearbandkeramik and the Bulgarian Neolithic cultures: differences and similarities. Vegetation History and Archaeobotany 14(4), 237-258.

Kreuz, A., Schäfer, E., 2011. Weed finds as indicators for the cultivation regime of the early Neolithic Bandkeramik culture? Vegetation History and Archaeobotany 20(5), 333-348.

Marinova, E., Thiebault, S., 2008. Anthracological analysis from Kovacevo, southwest Bulgaria: woodland vegetation and its use during the earliest stages of the European Neolithic. Vegetation History and Archaeobotany 17(2), 223-231

McClatchie. M., 2003. The plant remains, in: McLoughlin, C., Kerloge, Co. Wexford, 02E0606. Stafford McLoughlin Archaeology, Unpublished excavation report.

McClatchie, M., 2007. The study of plant macro-remains: investigating past societies and landscapes, in: Murphy, E., Whitehouse, N. (Eds.), Environmental archaeology in Ireland. Oxbow, Oxford, pp. 195-220.

McClatchie, M., 2009. Arable agriculture and social organisation: a study of crops and farming systems in Bronze Age Ireland. Institute of Archaeology, University College London, Unpublished PhD thesis.

McClatchie, M., (accepted). Cultivating societies: assessing the evidence for cereal remains in Neolithic Ireland, in: Whitehouse, N., Schulting, R., McClatchie, M. (Eds.), Living landscapes: exploring Neolithic Ireland and its wider context.

McClatchie, M., Bogaard, A., Colledge, S., Whitehouse, N.J., Schulting, R.J., Barratt, P., McLaughlin, T.R., in preparation. The introduction of agriculture into Ireland: a review of the plant macro-remains evidence.

McSparron, C., 2008. Have you no homes to go to? Arch.Irl. 22(3), 18-21. 
Monk, M., 1988. Appendix 3. Archaeobotanical study of samples from pipeline site, in: Gowen, M. (Ed.), Three Irish gas pipelines: new archaeological evidence in Munster. Wordwell, Dublin, pp. 185-191.

Monk, M.A., 2000. Seeds and soils of discontent: an environmental archaeological contribution to the nature of the early Neolithic, in: Desmond, A., Johnson, G., McCarthy, M., Sheehan, J., Shee Twohig, E. (Eds.), New agendas in Irish prehistory: papers in commemoration of Liz Anderson. Wordwell, Bray, pp. 67-87.

Monk, M.A., in preparation. Appendix D: Plant remains report on the samples from the 1987-1989 seasons, in: Gowen, M. (Ed.), Excavations at Tankardstown South, Kilmallock, Co. Limerick, 1987-1989. Tankardstown 2.

Out, W., 2010. Sowing the seed? Human impact and plant subsistence in Dutch wetlands during the Late Mesolithic and Early and Middle Neolithic (5500-3400 cal BC). Leiden University Press, Leiden.

Rösch, M., 2000. Anthropogener Landschaftswandel in Mitteleuropa während des Neolithikums. Germania 78, 293-318.

Rowley-Conwy, P., 2011. Westward ho! the spread of agriculture from Central Europe to the Atlantic. Curr. Anthropol. 52 (suppl. 4), S431-S451.

Salavert, A., 2011. Plant economy of the first farmers of central Belgium (Linearbandkeramik, 5200-5000 B.C.). Vegetation History and Archaeobotany 20(5), 321-332.

Schulting, R.J., Murphy, E., Jones, C., Warren, G., 2012. New dates from the north, and a proposed chronology for Irish court tombs. Proc. Royal Irish Acad. 112C, 1-60.

Schulting, R.J., Whitehouse, N.J., Barratt, P., McLaughlin, T.R., McClatchie, M., Bogaard, A., et al. in preparation. Dating cereals in Neolithic Ireland. 
Shennan, S.J., Conolly, J., 2007. The origin and spread of Neolithic plant economies in the Near East and Europe. (Available at http://ads.ahds.ac.uk/catalogue/archive/neoplants ahrb 2005/index.cfm; Last accessed $23^{\text {rd }}$ January 2012).

Sheridan, A., 2003. French connections I: spreading the marmites thinly, in: Armit, I., Murphy, E., Nelis, E., Simpson, D. (Eds.), Neolithic settlement in Ireland and western Britain. Oxbow, Oxford, pp. 3-17.

Sheridan, A., 2010. The Neolithization of Britain and Ireland: the 'big picture', in: Finlayson, B., Warren, G. (Eds.), Landscapes in transition. Oxbow, Oxford, pp. 89105.

Simpson, D.D.A., 1995. The Neolithic settlement site at Ballygalley, Co. Antrim, in: Grogan, E., Mount, C. (Eds.), Annus Archaeologiae: archaeological research 1992. Organisation of Irish Archaeologists, Dublin, pp. 37-44.

Stace, C., 1997. New flora of the British Isles. Cambridge University Press, Cambridge.

Smyth, J., 2006. The role of the house in Early Neolithic Ireland. Eur. J. Archaeol. 9 (2-3), 229-257.

Smyth, J., 2010. The house and group identity in the Irish Neolithic. Proc. Royal Irish Acad. 111C, 1-31.

Thomas, J., 1999. Understanding the Neolithic. Routledge, London.

Thomas, J., 2003. Thoughts on the 'repacked' Neolithic revolution. Antiquity 77, 6774.

Thomas, J., 2004. Current debates on the Mesolithic-Neolithic transition in Britain and Ireland. Documenta Praehistorica 31, 113-130. 
Thomas, J., 2008. The Mesolithic-Neolithic transition in Britain, in: Pollard, J. (Ed.), Prehistoric Britain. Blackwell, Oxford, 58-89.

van der Veen, M., Jones, G., 2006. A re-analysis of agricultural production and consumption: implications for understanding the British Iron Age. Vegetation History and Archaeobotany 15(3), 217-228.

Vaughan-Williams, A., 2007. Appendix 2: archaeobotanical analysis; in: Bowen, P. (Ed.), Archaeological excavations at Caw, Waterfoot, Co. Derry, 125-8. Archaeological Development Services Ltd, Unpublished excavation report.

Wasylikowa, K., 1981. The role of fossil weeds for the study of former agriculture. Zeitschrift für Archäologie 15, 11-23.

Whitehouse, N.J., McClatchie, M., Barratt, P., Schulting, R., McLaughlin, R., Bogaard, A., 2010. INSTAR - Cultivating Societies. Archaeol. Irel. 24(2), 16-19.

Whitehouse, N.J., Schulting, R.J., McClatchie, M., Barratt, P., McLaughlin, R., Bogaard, A., Colledge, S., Marchant, R., Gaffrey, J., Reimer, P., Brown, D., submitted. Neolithic agriculture on the western fringes of Europe: a multi-disciplinary approach to the boom and bust of early farming in Ireland. Submitted to J. Archaeol. Sci.

Zohary, D., Hopf, M., 2000. Domestication of plants in the Old World. Oxford University Press, Oxford.

\section{Table captions}

Table 1: Chronological categories relating to examined sites

Table 2: Site types from which archaeobotanical remains were derived 
Table 3: Relative occurrence of wheat grains versus wheat glume bases at database sites where these remains were recorded (sites $n=4$ )

Table 4: Number of weed taxa per site (only charred weed seeds were included in analysis; sites $n=18$ )

Table 5: Charred weed taxa from Irish sites that were subject to ecological analyses (it is possible that at least some of the Avena finds represent later intrusions; none has been directly radiocarbon dated to the Neolithic period)

\section{Figure captions}

Fig. 1: Map of Ireland showing locations of sites where plant remains were recorded

Fig. 2: Relative occurrence of plant categories (sites $n=52$ )

Fig. 3: Relative occurrence of cereal types at sites where cereals were recorded (sites $n=40$; dark grey = wheat types; light grey = barley types; stripe = indeterminate cereal)

Fig. 4: Number of charred cereal grains at sites where grains were quantified (sites $n=30$ ), grouped by number of samples where any plant remains were present

Fig. 5: Major habitat associations (Ellenberg et al., 1992) of potential arable weed taxa from Neolithic Ireland (taxa $n=12$ ), Britain (taxa $n=45$ ) and the loess belt of central Europe (taxa $n=109$ ). British and loess belt data derive from Bogaard and Jones (2007; accepted).

Fig. 6: Proportions of annual and perennial potential arable weed taxa from Neolithic Ireland (taxa $n=13$ ), Britain (taxa $n=54$ ) and the loess belt of central Europe (taxa $n$ $=126$ ). British and loess belt data derive from Bogaard and Jones (2007; accepted). 
Fig. 7: Comparison of crop types by region from aceramic and Early Neolithic sites where cereals were present, expressed as percentage presence per region. Data source for non-Irish results is Shennan and Conolly, 2007.

Fig. 8: Wheat chaff impressions on ceramic vessel from Dooey's Cairn, Ballymacaldrack, Co. Antrim. Photograph reproduced courtesy the Trustees of National Museums Northern Ireland. Photograph @ National Museums Northern Ireland, Collection Ulster Museum.

Fig. 9: Relative occurrence of einkorn and emmer wheat at Early Neolithic sites in different regions, expressed as percentage presence per region. Data source for non-Irish results is Shennan and Conolly, 2007. Further information on dating of the Early Neolithic period in each area can be found in Colledge et al., 2005. 


\section{Highlights}

- A much-enlarged archaeobotanical dataset from Neolithic Ireland has been collated.

- Cereals were recorded at many locations, most often at earlier Neolithic sites.

- It appears cultivation plots were not managed under a shifting cultivation regime.

- A decrease in crop diversity is apparent as agriculture spread towards Ireland. 


\section{Tables}

\begin{tabular}{ll}
\hline Period & Date range \\
\hline EN I & $4000-3750$ cal BC \\
EN II & $3750-3600$ cal BC \\
MN I & $3600-3400$ cal BC \\
MN II & $3400-3000$ cal BC \\
LN & $3000-2500$ cal BC \\
\hline
\end{tabular}

Table 1

\begin{tabular}{|c|c|c|}
\hline Period & Number of sites & Types of sites \\
\hline EN II & 28 & $\begin{array}{l}\text { Mainly rectangular structures or 'houses' } \\
\text { (single and multiple); also pit complexes, non- } \\
\text { rectangular structures and possible structures, } \\
\text { causewayed enclosure, barrow, burnt mound } \\
\text { sites }\end{array}$ \\
\hline MN I & 10 & $\begin{array}{l}\text { Mainly pit and post-hole complexes; also four- } \\
\text { post structure, possible structure, burial site }\end{array}$ \\
\hline MN II-LN & 11 & $\begin{array}{l}\text { Pit/post-hole complexes, structures and } \\
\text { possible structures, passage tombs }\end{array}$ \\
\hline Indet. Neolithic & 3 & $\begin{array}{l}\text { Cremation pit complex and nearby settlement, } \\
\text { possible habitation site, multiple palisade }\end{array}$ \\
\hline
\end{tabular}

Table 2

\begin{tabular}{llll}
\hline Site type & No. components & $\%$ Grain & $\%$ Chaff \\
\hline Rectangular structure & 38 & $66 \%$ & $34 \%$ \\
Rectangular structure & 1798 & $80 \%$ & $20 \%$ \\
Burnt mounds & 206 & $80 \%$ & $20 \%$ \\
Pit complex & 12 & $92 \%$ & $8 \%$ \\
\hline
\end{tabular}

Table 3

\begin{tabular}{ll}
\hline No. weed taxa & $\begin{array}{l}\% \text { sites where } \\
\text { present }\end{array}$ \\
\hline
\end{tabular}




\begin{tabular}{ll}
\hline 1 taxon & $61 \%$ \\
$2-5$ taxa & $28 \%$ \\
$>5$ taxa & $11 \%$ \\
\hline
\end{tabular}

Table 4

\begin{tabular}{lccc}
\hline Taxon & $\begin{array}{c}\text { Number of sites } \\
\text { where recorded }\end{array}$ & $\begin{array}{c}\text { Ellenberg ecological } \\
\text { category }\end{array}$ & $\begin{array}{c}\text { Annual/ } \\
\text { Perennial }\end{array}$ \\
\hline Avena spp. & 5 & disturbed & $\mathrm{a}$ \\
Cladium mariscus (L.) Pohl & 1 & freshwater/moorland & $\mathrm{p}$ \\
Galium aparine L. & 4 & disturbed & $\mathrm{a}$ \\
Hyoscyamus niger L. & 1 & disturbed & $\mathrm{a}$ \\
Lapsana communis L. & 1 & disturbed & $\mathrm{a}$ \\
Lolium temulentum L. & 1 & disturbed & $\mathrm{a}$ \\
Menyanthes trifoliata L. & 1 & freshwater/moorland & $\mathrm{p}$ \\
Plantago lanceolata L. & 2 & grassland & $\mathrm{p}$ \\
Polygonum aviculare L. & 2 & disturbed & $\mathrm{a}$ \\
Ranunculus flammula L. & 1 & dreshwater/moorland & $\mathrm{p}$ \\
Raphanus raphanistrum L. & 1 & indeterminate & $\mathrm{a}$ \\
Rumex acetosella L. & 1 & disturbed & $\mathrm{p}$ \\
Tripleurospermum inodorum & 1 & & $\mathrm{a}$ \\
(L.) Sch. Bip. & & &
\end{tabular}

Table 5 


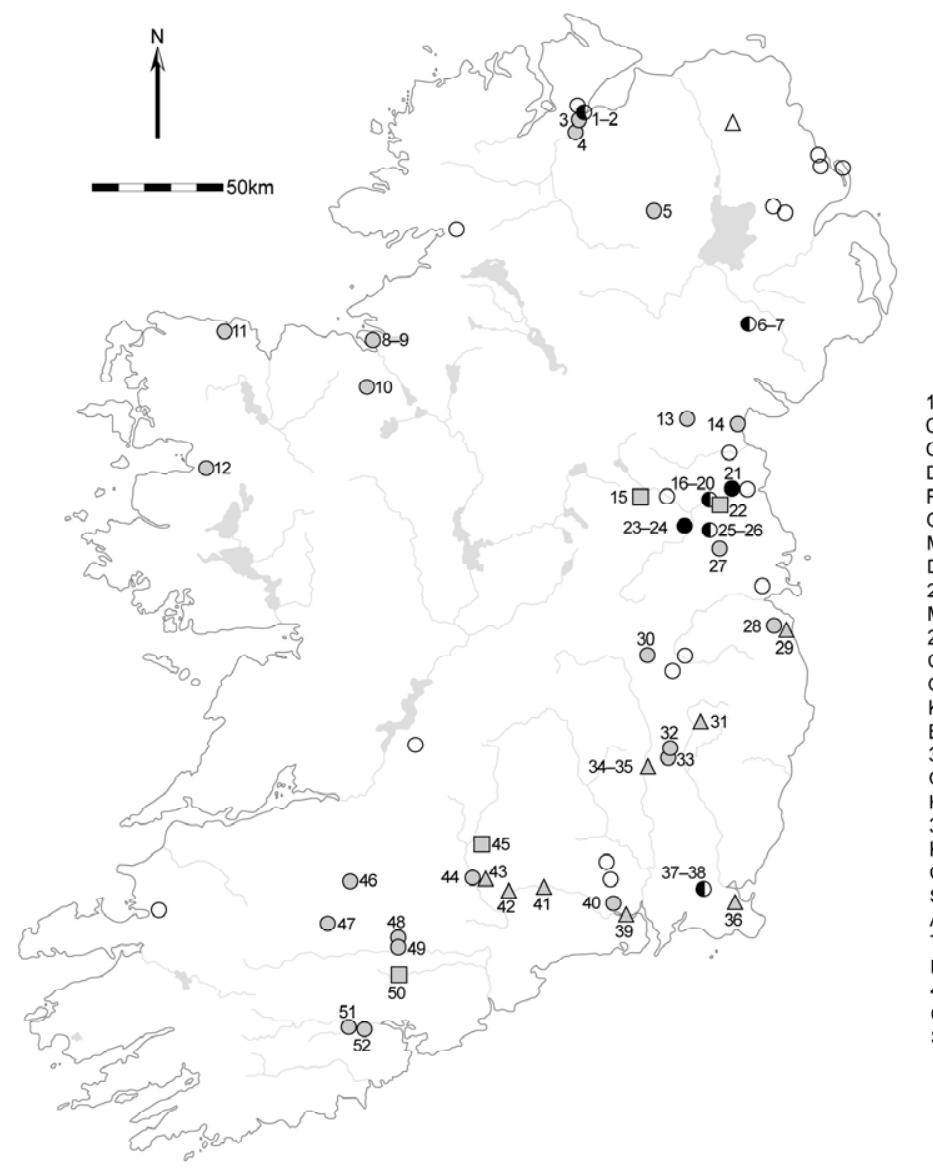

O EN II

$\triangle \mathrm{MN}$ I

$\square \mathrm{MN}$ II-LN

- EN II and MN-LN

- NEO

Non-database (cereal)

$\triangle$ Cereal impression

1-2: Enagh, Sites 2 \& 3, Co. Derry; 3: Gransha, Sites 11 \& 12 , Co. Derry; 4: Caw, Area 4, Co. Derry; 5 : Ballynagilly, The Corbie, Co. Tyrone; 6-7: Ballintaggart, Areas 1 \& 2, Co. Down; 8-9: Magheraboy, Sites 2B \& 2C, Co. Sligo; 10 Rathdooney Beg, Co. Sligo; 11: Ballyglass, Co. Mayo; 12 Gortaroe, Site 2, Co. Mayo; 13: Monanny, Site 1, Co Monaghan; 14: Haggardstown, Site 13, Co. Louth; 15 Drumbaragh, Site 1, Co. Meath; 16-20: Knowth, Co. Meath; 21: Townleyhall, Site II, Co. Louth; 22: Newgrange, Co. Meath; 23-24: Castletown Tara, Sites 1 \& 2, Co. Meath 25-26: Lismullin, Site 1, Co. Meath; 27: Clowanstown, Site 1. Co. Meath; 28: Kilgobbin, Areas 3 \& 6, Co Dublin; 29 : o. Meath, 28. Klyobbin, Areas 3 \& 6, Co. Dublin, 29 . Kildar 31: Pinnacl Coolinarig Upper and Tuckmill Kildare, 31. Pinnacle, Coolinarrig Upper and Tuckmill Hill, Baltinglass Hill, Co. Wicklow; 32: Russellstown, Co. Carlow; 33; Busherstown, Area 6, Co. Carlow; 34-35: Ballybannon, Co. Carlow; 36: Kerloge, Sites 3 \& 5, Co. Wexford; 37-38: Harristown Big, Areas 1 \& 2, Co. Wexford; 39: Newrath, Site 35 , Co. Kilkenny; 40: Granny, Site 27, Co. Kilkenny; 41: Kilsheelan, Poulakerry and Cloghcarigeen East, Areas 1 \& 2, Co. Tipperary; 42: Marlfield, Co. Tipperary; 43: Suttonrath, Site 206.1, Co. Tipperary; 44: Caherabbey Upper, Site 185.1 Area 1, Co Tipperary: 45: Lough Feedora, Site 173.1, Co. Tipperary: 46: Tankardstown South Toperary, 46. Tankardstown South, Co. Limerick, 47 Peppernill, Co. Cork, 48. Ballinglanna North, Ste 3, Co. Cork; 4. Corte, Site 1, Co. Cork; 50: Curraghrevin, So. Cor, Co. Cork; 51: Barnagore, Site 3, Co. Cork; 52: Ballinaspig More Site 5, Co. Cork. 


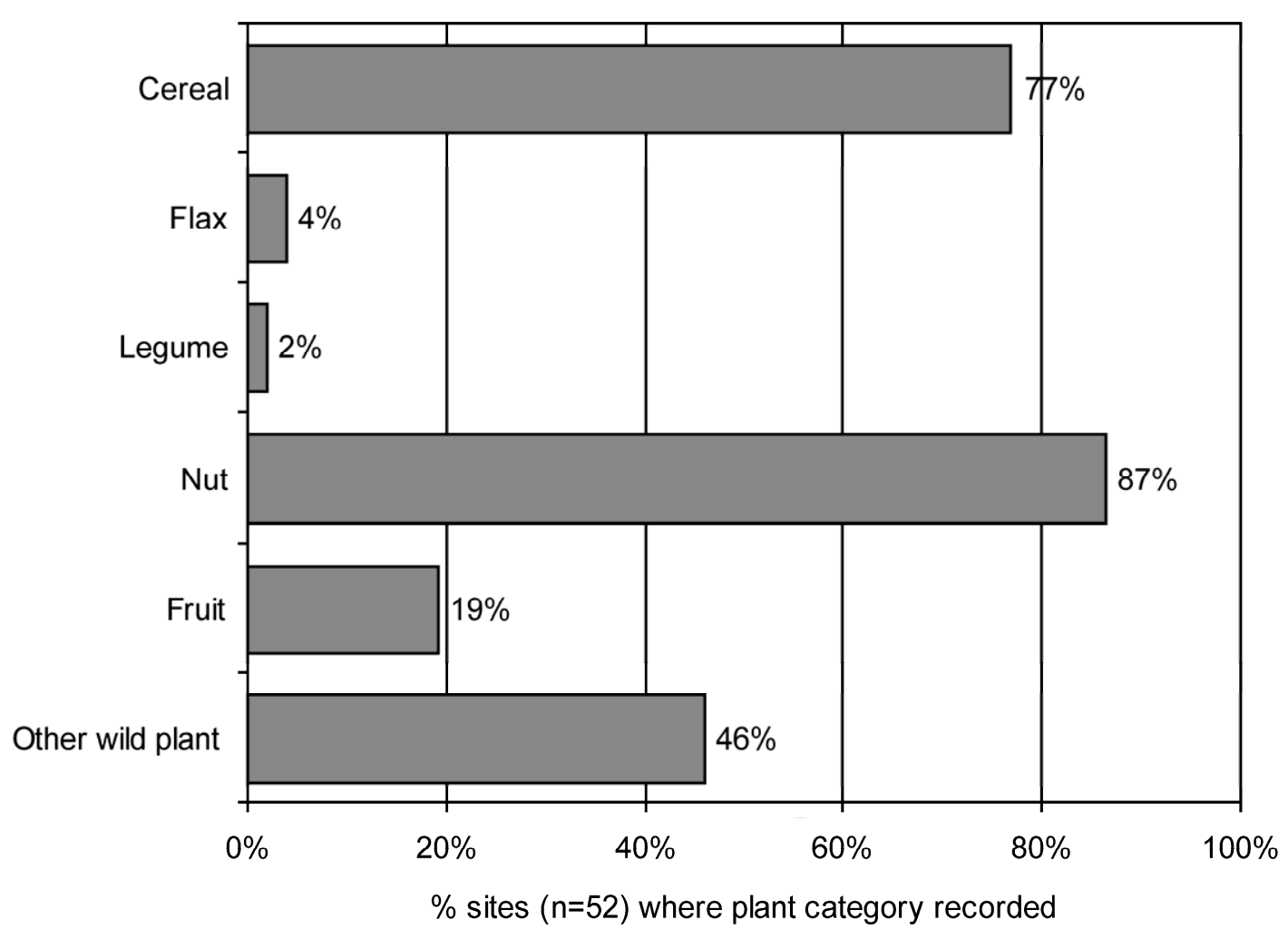




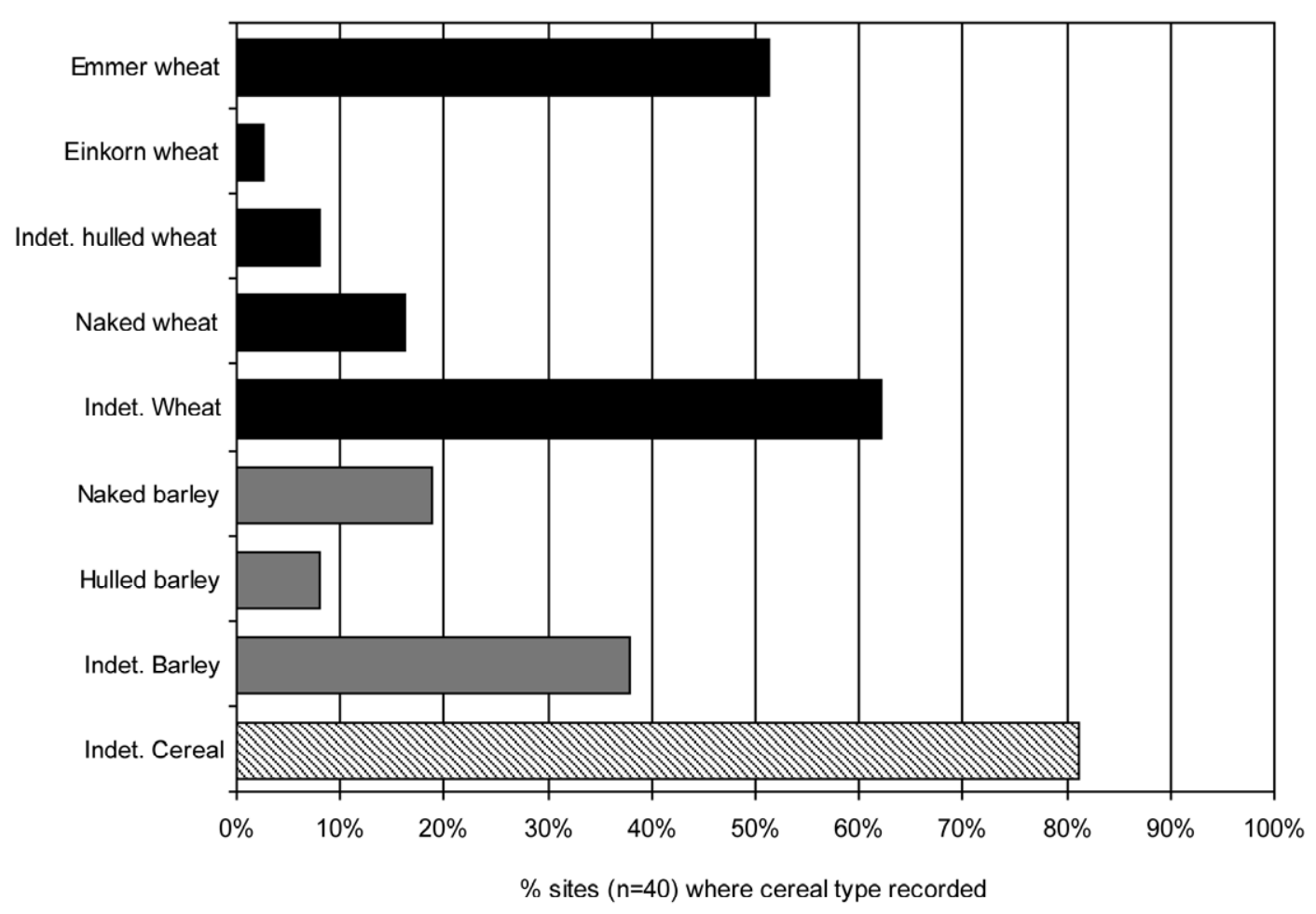




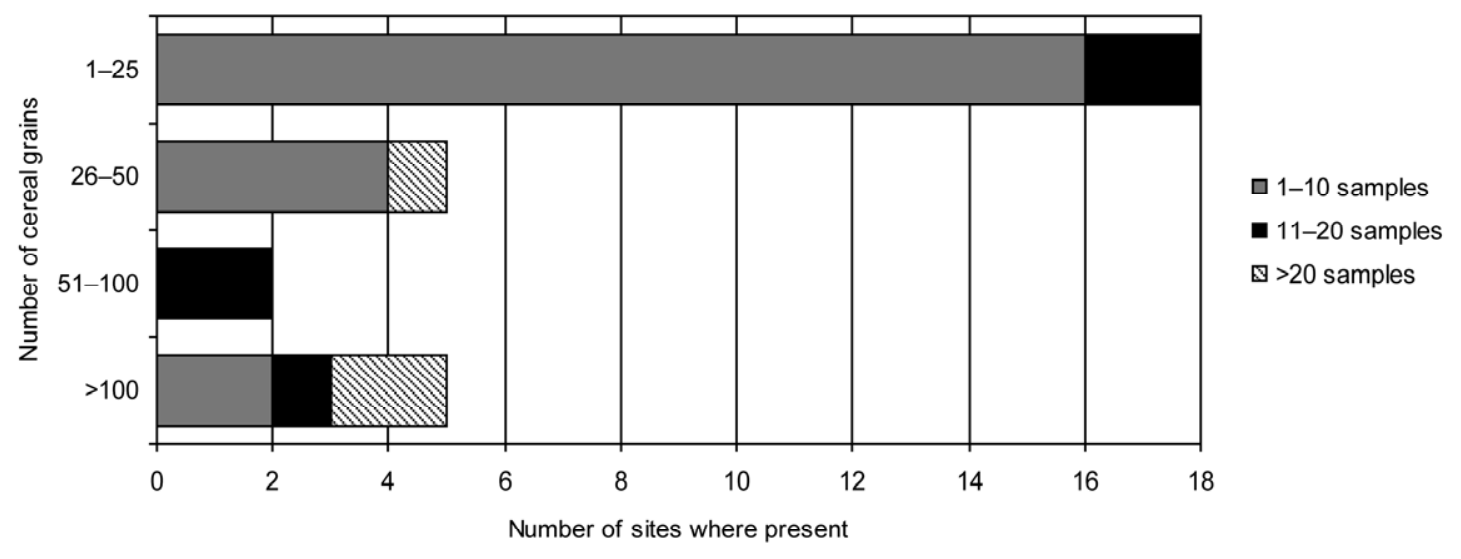




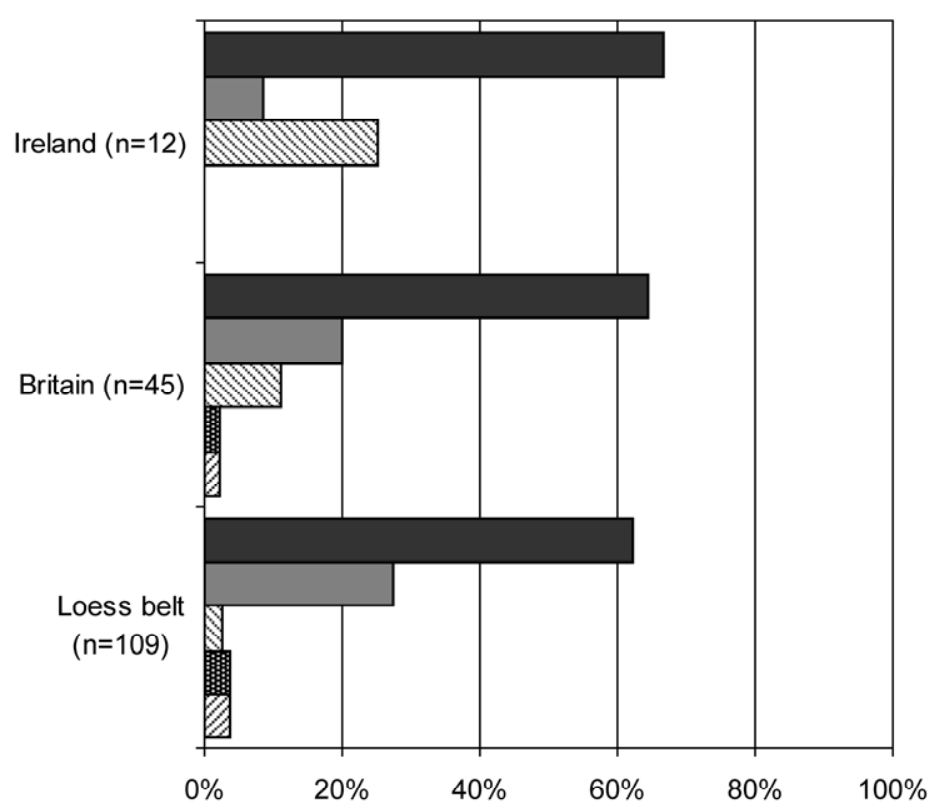

- Disturbed places

$\square$ Grassland

\& Freshwater/Moorland

目 Woodland edge

$\checkmark$ Woodland 


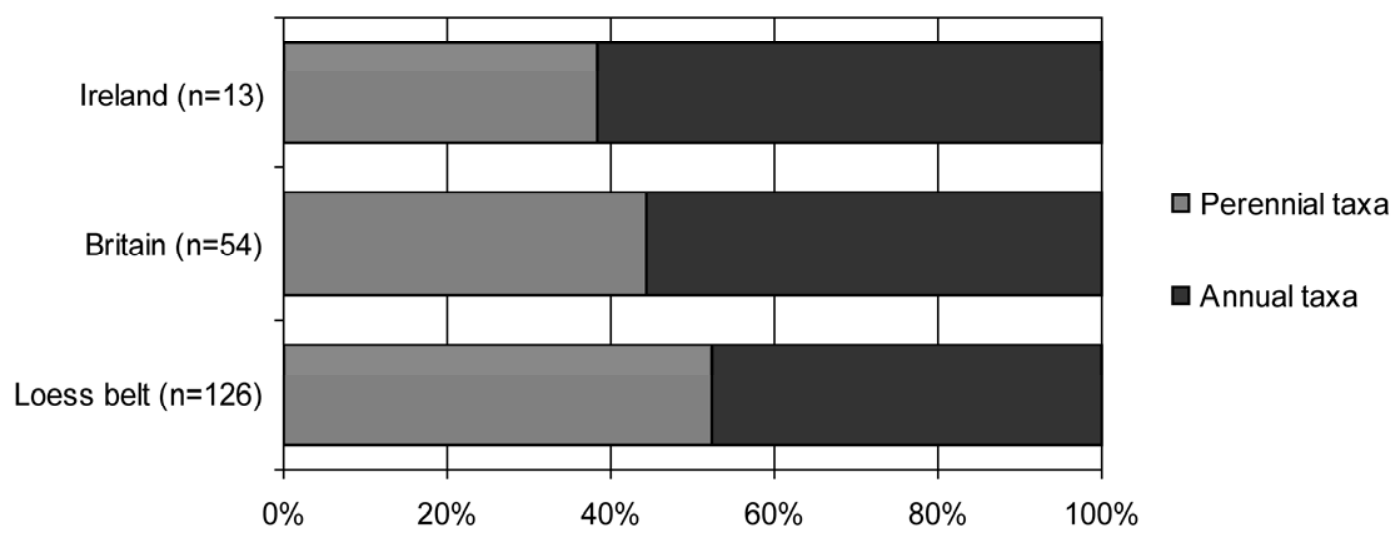




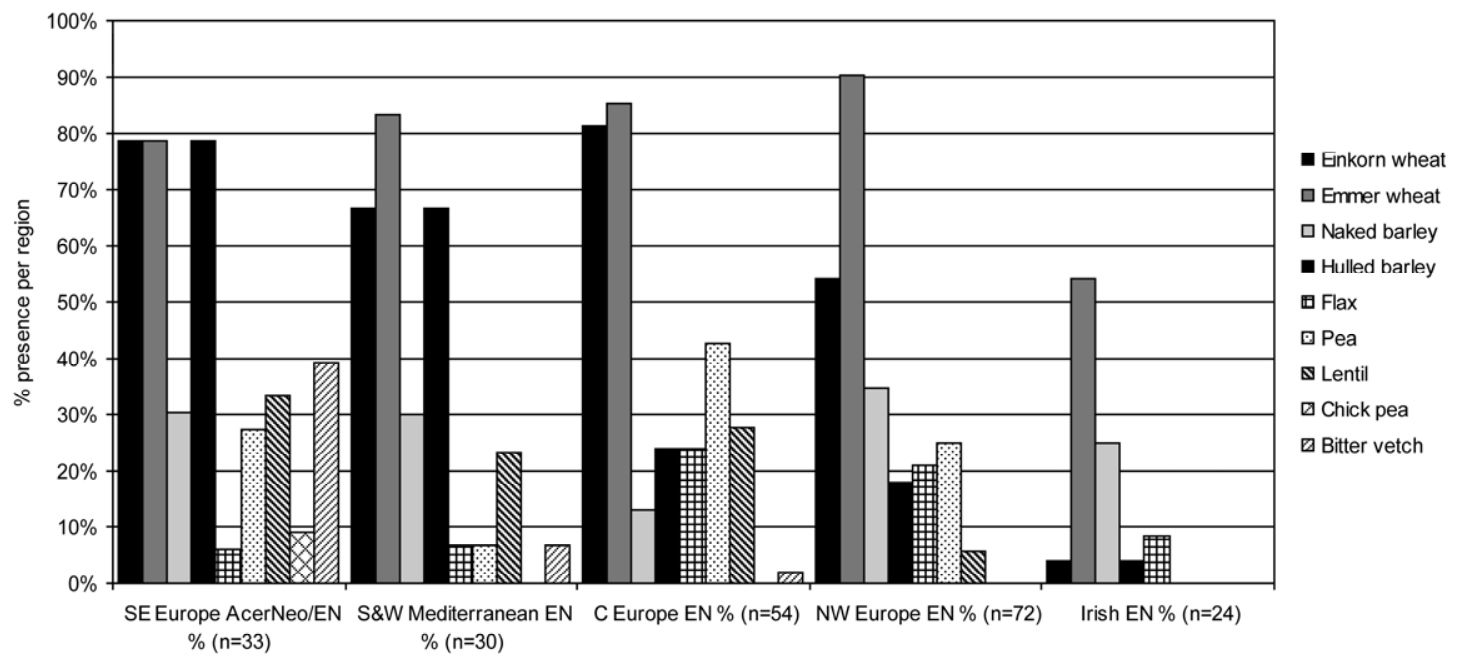




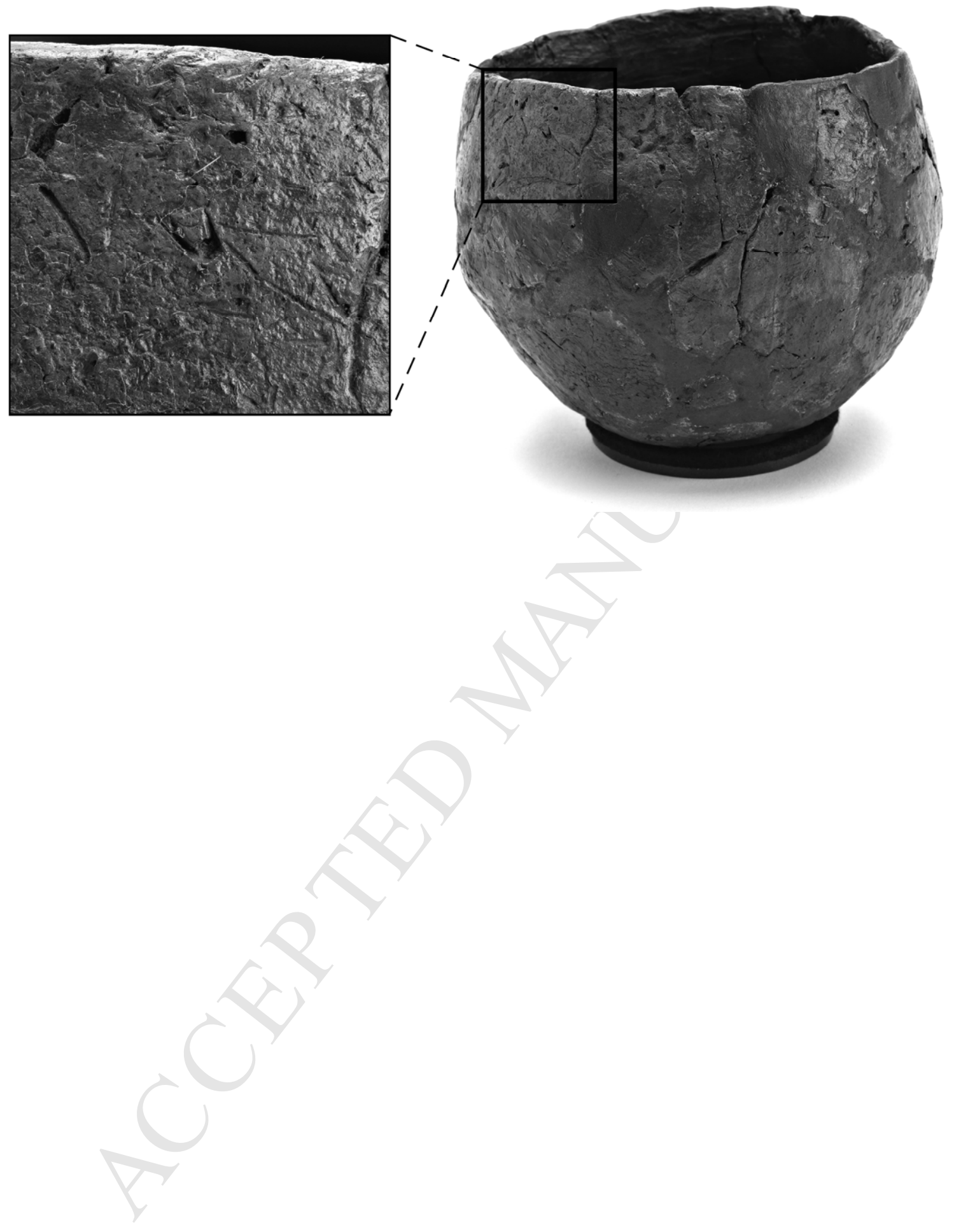




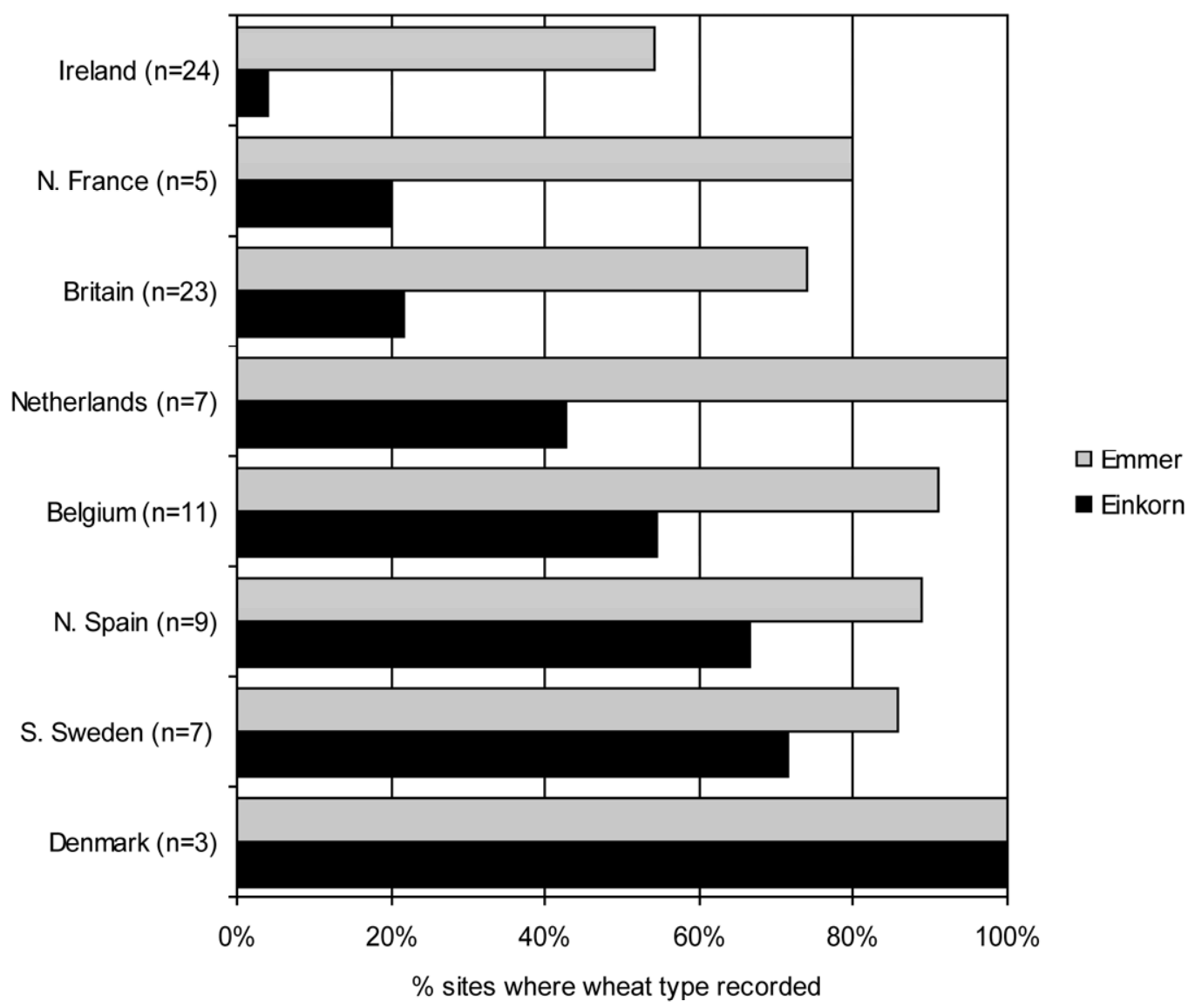

